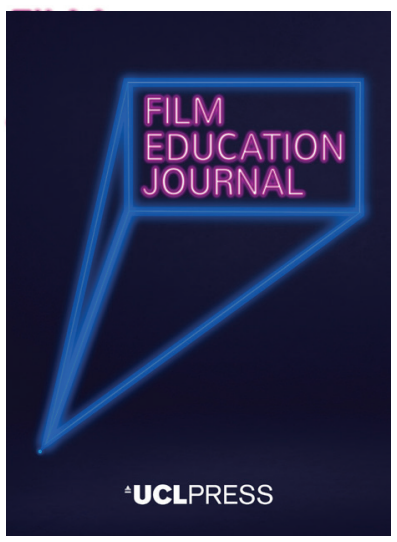

UCLPRESS

FILM EDUCATION JOURNAL

ISSN 2515-7086 (Online)

Journal homepage:

https://www.uclpress.co.uk/pages/film-education-journal

\title{
Children coping with COVID-19: Intersectional understandings of film and media access in a crisis
}

\author{
Justine Atkinson (iD) and Firdoze Bulbulia (iD
}

\section{How to cite this article}

Atkinson, J. and Bulbulia, F. (2021) 'Children coping with COVID-19: Intersectional understandings of film and media access in a crisis'. Film Education Journal, 4 (1), 29-43. https://doi.org/10.14324/FEJ.04.1.03

Submission date: 14 August 2020

Acceptance date: 13 November 2020

Publication date: 10 June 2021

\section{Peer review}

This article has been peer-reviewed through the journal's standard double-blind peer review, where both the reviewers and authors are anonymized during review.

\section{Copyright}

(C) 2021 Atkinson and Bulbulia. This is an open-access article distributed under the terms of the Creative Commons Attribution Licence (CC BY) 4.0 https://creativecommons.org/licenses/ by/4.0/, which permits unrestricted use, distribution and reproduction in any medium, provided the original authors and source are credited.

\section{Open access}

The Film Education Journal is a peer-reviewed open-access journal. 


\title{
Children coping with COVID-19: Intersectional understandings of film and media access in a crisis
}

\author{
Justine Atkinson* - University of Glasgow, UK \\ Firdoze Bulbulia* - University of Johannesburg, South Africa
}

\begin{abstract}
As a result of the global COVID-19 pandemic and resulting lockdowns across the world, digital access has become paramount, as most aspects of education have moved online. Drawing together five case studies located in South Africa, Argentina, the Netherlands, India and Ethiopia, this article assesses the role of film education during the COVID-19 pandemic, with a specific focus on the impacts of digital access. We examine multimodal forms of film education, and how these were used to inform, entertain and educate children during the crisis by the varying work undertaken by the organizations. Applying theories of intersectionality, we address the need for context-specific approaches to film education, focusing upon the impact that the societal and individual contexts had on the dissemination of film education in each country.
\end{abstract}

Keywords: intersectionality, children, film education, digital access

There can be no keener revelation of a society's soul than the way in which it treats its children. (Nelson Mandela, 1995, in Nelson Mandela Children's Fund, 2021)

In unprecedented times, the COVID-19 pandemic has, at the time of writing, necessitated that over a third of countries institute forms of lockdown. The resulting impacts, including restricted movement, closed businesses and separated families, have changed life as we know it. The broad socio-economic impacts of the pandemic are still being realized as the virus continues to cause severe difficulties in many parts of the world. Although COVID-19 operates relatively indiscriminately as a virus, responses from countries have differed widely, from the enforcement of lockdown measures, to financial aid, health care and the way in which aspects of knowledge are disseminated. On a global level, the impacts of the response to COVID-19 have highlighted the fragility of neoliberal capitalism, with increasing emphasis upon state intervention to support private business. Inequality has also been exacerbated through a rise in work precarity, access to education and the provision of government financial aid. Throughout this article we look specifically at the impact some of these measures have had upon children (ages 5-16), and the educational responses from media and film organizations directed towards children.

Although children are thought to be less directly at risk than adults from the virus itself, this does not negate the impact of broader socio-economic, demographic and geographical factors upon children's development. Children must still contend with the collateral impacts of the financial, emotional and physical implications of COVID-19 upon their families, carers and wider environment. The impact upon 
children will, however, differ greatly depending on geographical and socio-economic location, influenced by factors including (but not limited to) financial security, quality of education (at home and at school), health care and stability of home life. This article will focus on the complementary roles that film education has played to date in the pandemic, in terms of disseminating information, and providing education, connection and comfort during the COVID-19 crisis. In doing so, we seek to overcome the peripherality of non-Western perspectives within film education discourses, drawing together five case studies from organizations across the world: the Children and Broadcasting Foundation for Africa (CBFA; South Africa); Takalani Sesame (South Africa); My \#QuarantineLife (Argentina and the Netherlands); Smile International Film Festival for Children and Youth (SIFFCY, India); and Whiz Kids Workshop (Ethiopia). We critique notions of universalism within film education (Chambers, 2018; Akande, 2020; Bachmann and Zahn, 2018), looking at how societal and individual intersectionality (specifically race, class, language, geographical location and context) (Crenshaw, 1991; Núñez, 2014) influenced access to, and engagement with, the film education initiatives. In doing so, we draw in part upon Alain Bergala's (2016) notion of the passeur as an educational informer as a point of departure in assessing the multimodality of the different forms of film education discussed. Looking beyond formal film educational institutions, the article focuses on the role of film festivals, production companies and media organizations, with a specific focus on digital access to education (DeHart, 2020). We argue that consumption of film education is impacted by intersectionality, and that the discourses around film education therefore require a context-driven and heterogeneous approach, taking into account the particular forms and responses that film education may take within each sociocultural location.

\section{Framing film education discourses within an intersectional perspective}

Intersectionality was formalized in scholarly debate in the 1980s and 1990s. It primarily emerged in critical race studies as a result of problematizing the 'colour-blindness, neutrality, and objectivity' of the law (Nash, 2008: 2). The term was first coined by Kimberlé Crenshaw (1991), who asserted the need to recognize Black women's race as well as their gender in law. Although its origins are derived from linking race and gender, the term has proliferated to include a broader cross-section of individual and societal identity markers. As it has been adopted more widely by scholars, the term has transformed and expanded, so that an assessment of intersectionality has become more broadly entwined with privilege and marginalization, and with the manner in which 'race, class, gender, sexuality, ethnicity, nation, ability and age operate not as unitary, mutually exclusive entities, but as reciprocally constructing phenomena that in turn shape complex social inequalities' (Collins, 1990: 2). Intersectional perspectives thus require fluidity so that social definitions are seen not as fixed, but rather in constant flux, reflecting the specificities of the situation.

Theories of intersectionality have been critiqued for placing too much emphasis on individual identity markers, rather than looking at the broader structures that create them (Núñez, 2014: 85). As a result of this relatively limited application, Núñez (2014: 85) considers intersectionality to be an incomplete term 'that fails to address the role of structure as well as individual agency in shaping life chances in developing the associated strategies necessary to effect structural social change'. Based on this criticism, many scholars (Gross et al., 2016; Núñez, 2014) have sought to expand notions of intersectionality in order to emphasize the importance of the interplay between 
macro- and micro-levels at both individual and societal levels. Gross et al. (2016: 51) suggest that:

from an intersectional point of view, social inequality is not only determined multidimensionally along different axes of inequality - such as gender, migration, socioeconomic background, age, disability and so on - but emerges particularly in the intersection of these axes as they mutually constitute each other within social contexts such as the family, school or the labour market.

Intersectionality therefore requires both macro- and micro-perspectives in each context of application in order to fully grasp its impacts and effects.

Although studies of intersectionality are somewhat nascent within film education, they can be placed in parallel with existing approaches pursuing a contextspecific focus. Bachmann and Zahn (2018), for example, have suggested that film education is inextricably entwined with context, and with the spaces and institutions in which any given project is situated. Bachmann and Zahn (2018: 79) suggest that 'every form of film education is embedded in, and thus influenced by, its regional context, which both limits and facilitates its specific implementation'. Elaborating upon this, theories of intersectionality within film education must therefore assess contextual dynamics of power, and provide nuanced frameworks through which to look at the differing and complex influences within experiences of film education (Collins, 1990).

Akande (2020: 1) expounds the necessity of moving away from supposedly universal conceptions of film education as being focused on Western processes of knowledge dissemination, 'fostered [by] an ongoing, transnational sense of legitimacy, supremacy and universality in our perception of Western knowledge systems'. Through an examination of how film education in Nigeria stems from pre-colonial means of knowledge dissemination, Akande (2020) highlights the shift away from canonical texts in film learning, focusing instead on practical learning and the oral dissemination of information. In these terms, notions of universality within film education are problematic, for they frequently prohibit inclusivity and representational equity due to the field's Western-centrism. The application of intersectional perspectives may thus provide scope for overcoming such simplifications in allowing for a more nuanced understanding of film education.

While Chambers (2018) similarly cautions against the homogenizing tendencies of universalism, he cautiously advocates for its potential usefulness in bringing together a disparate field of film education through a certain pragmatic appeal to 'heterogeneous universalisms' (Chambers, 2018: 37). Given the peripheral, underfunded nature of film education worldwide, Chambers (2018: 37) highlights the need for film education theories to be drawn together into a holistic field, albeit one 'comprised of the disparate activities of diverse film education practitioners across the world'. He further emphasizes the importance of representation, and the need to ensure that film education is able to encompass diverse theories and experiences under its umbrella.

Given the similarities in the effects of the global pandemic in various parts of the world, it could be argued there are aspects of universal experience underlying film education responses to COVID-19, with each of the case studies below detailing initiatives to move education online. Despite these aspects of commonality, however, each societal context differs in its access to, and experience of, digital film education, through degrees of contingency and particularity that intersectional perspectives usefully help to illuminate. 
Throughout the COVID-19 pandemic to date, film education has been used as a means both to educate and inform children about the crisis, and to engage with film more directly. Through the case studies below, we assess the micro- and macroinfluences upon forms of film education in India, South Africa, Ethiopia, Argentina and the Netherlands, looking at how intersectional perspectives can reveal differing degrees of digital access, and the divergent ways in which children are able to receive education during the pandemic. The case studies seek, within the particular context of the pandemic, to look beyond the classroom to include a multiplicity of film education settings modalities, with film used both as a focus of learning in its own right, and often within the same project - of disseminating important information during the pandemic. Jason DeHart (2020: 46-7) describes how 'theories of multimodality centre upon the notion that communication can exist in a variety of modes, or platforms for communication', including 'clips and films in their entirety ... educational films, clips included as part of a curriculum, and popular films'. The following case studies of film education during the COVID-19 crisis will provide insights into the different ways that film has been used as an educational medium during the pandemic, and the intersectional challenges that inhibited children's learning due to the digital transition.

\section{SIFFCY and \#OneWorldChildren workshops - India}

The Smile International Film Festival for Children and Youth (SIFFCY) is a film festival and forum initiated by the Indian development organization the Smile Foundation. It is dedicated to showing children's film and media in India. The festival is hosted in New Delhi in December each year, bringing together film-makers, artists and industry professionals (Smile Foundation, 2020). The festival is curated by the Festival Director, Jitendra Mishra, who presides over both detailed aspects of the programme and the overall vision of the event. In using the film festival as an educational platform, Jitendra might be seen to act as a passeur, a term used by Bergala (2016) in describing someone who passionately introduces students to 'the world of cinephilia', providing access to films and film-making (Donald, 2019: 65), while often taking into account the fact that children need to simultaneously 'learn by viewing and learn by doing' (Gibbs, 2018: 94). SIFFCY caters for young people (ages 6-25), creating opportunities for them to engage with film on multiple levels - from watching and engaging with content, to creating their own films, to learning about developing their own careers in the film industry. As Jitendra Mishra explained in an interview with the authors on 30 July 2020, his core aim in this respect is to inspire cinephilia in the children he reaches, teaching them appreciation of film and film-making practices, and to do this through film screenings and workshops from across the world as part of the festival.

As physical meetings were restricted, the COVID-19 lockdown required SIFFCY to reconsider how they could continue to cater for children within a digital arena. In order to do this, it was decided to move the festival online, through co-hosting the \#OneWorldChildren online campaign, held for two months in May and June 2020. According to Jitendra in the interview, the campaign was inspired by the universal notion of a oneness of humanity: 'although we are separated by religion, country, social status, we are all one. COVID-19 provided the possibility for us to explore what we couldn't explore earlier; this is the only situation in a lifetime that everyone across the world has the same enemy.'

Following this vision, SIFFCY partnered with other festivals globally to bring in expert speakers and film-makers who would share their work with young audiences in India. To do so, the festival undertook a combined approach of workshops and 
film screenings. Workshops focused on providing practical information, teaching children animation practices with experts from India, Iran, Belgium, Argentina, Russia and Mexico. Alongside this, participants also learnt about the importance of cybersecurity and film-making more broadly, as Jitendra explained in the interview. Film screenings were hosted online through private viewing links that were sent to those who subscribed to the festival. Every film in the programme was viewed by about a thousand children, and workshops were broadcast live on Facebook, reaching approximately ten thousand people per workshop.

Due to the digital nature of the festival, every child who engages with SIFFCY undertakes their 'own individual experience through their encounter with film', and is supported and guided (albeit at a distance, through curatorial choices) by Jitendra Mishra. While Jitendra takes responsibility for the selection of films in the programme, he leaves the interpretation up to participants, thereby seeking to grant them freedom in developing their own tastes in cinema (Bachmann and Zahn, 2018: 80). The festival also operates outside the institutional structures which Bergala (2016) considers frequently stand in the way of a true appreciation of 'cinema as an art form', due to the tendency to establish tight structures and the 'standardisation of taste' (Bachmann and Zahn, 2018: 80). In these terms, Jitendra might be seen to act as a passeur in the transference of film as an art form to be appreciated independently, thus providing a unique platform through which film education can take place in India.

Despite the worthy, universalist intentions underlying the \#OneWorldChildren campaign, intersectional perspectives reveal the ways in which both macro- and microfactors affect the reach of SIFFCY's digital initiatives, thus hindering their ability to be fully inclusive and equitably accessible.

In India, access to the opportunities offered by SIFFCY can be seen to be impacted by complex intersections of class, language and geographical location. A recent report compiled by Oxfam found that the top 10 per cent of Indian society holds 77 per cent of the total national wealth, and that 73 per cent of the wealth generated in 2017 went to the richest 1 per cent, while 63 million Indians from lower socio-economic backgrounds are not able to access health care and education services (Oxfam International, 2021). From a macro perspective, aspects of (structural) inequality are thus highly pervasive, and the challenges associated with this penetrate many areas of society, including economic, educational and health-care spheres. Although access to education is universal, it is unevenly influenced by 'class, caste, language, region, developmental (urban and rural) and gender divides' (Misra and Mishra, 2020).

When schools closed across India in March 2020, the turn to digital learning brought these structural divides even more to the fore. Access to technology and data is fairly widespread across India. In 2020, around 50 per cent of people had access to the internet, a significant increase from five years earlier (27 per cent), making India the world's second-largest internet user base (Misra and Mishra, 2020). Mobile phones and tablets are relatively easy to procure, proving affordable to much of the population, meaning that people from lower socio-economic backgrounds are able to access the internet (Misra and Mishra, 2020). Nevertheless, connectivity is still a problem, and socio-economic background is not the only contributing factor. According to a recent report compiled by the Internet and Mobile Association of India, 'on [a] national level, fewer women (33 per cent) have access to the internet compared to men (67 per cent), with rural areas experiencing more disparities (28-72) compared to urban areas (3862)', factors which also influence access to digital learning processes (Misra and Mishra, 2020). Internet access is also affected by provincial governments, with particularized approaches to data roll-out meaning that penetration varies across the country. 
Additionally, most people use mobile data, rather than the more reliable option of a fixed line, with some families also sharing devices, meaning that access to education is uneven across states. This is compounded by uneven and unreliable electricity supplies, which can cause mobile devices to run out of power (BBC News, 2020). Furthermore, while mobile devices are relatively cheap to obtain, many students from low socioeconomic backgrounds do not have internet access, and if they do, connection is slow and unreliable, and content is not produced in vernacular languages. This in turn creates structural barriers to accessing educational materials offered online, meaning that SIFFCY was unable to roll out education programmes in a fully equitable manner across the country (Misra and Mishra, 2020).

According to Jitendra Mishra, the digital transition overall has had a positive impact upon SIFFCY's work, enabling it to reach more children across India, without the physical barriers of location, distance and travel within the country. A digital arena also enabled cross-country partnerships and exchanges, meaning that children in India were able to watch films and learn from other film-makers and film experts around the world. Despite the extended outreach that the digital transition allowed in terms of breaking down physical barriers, however, the prohibitive intersection of macrostructures of digital access and structural inequality impacted children's access to the festival. In particular, children from disadvantaged socio-economic backgrounds, who speak regional languages and who live in rural areas across India were unable to take part. This intersectional understanding of film education in India thus shows that, despite making possible extra-institutional encounters with film, and strongly advocating for both practical and theoretical approaches to film education, the reach was limited by the wider infrastructural problems impacting access to technology and equipment needed to engage with the festival's programme of events. In this respect, the role of the passeur and film educator was bound and limited in reach by the context in which the festival took place.

\section{Whiz Kids Workshop - Ethiopia}

Whiz Kids Workshop is an organization based in Addis Ababa, Ethiopia. Established in 2005 by husband-and-wife team Shane Etzenhouser and Bruktawit Tigabu, the organization has been working in educational entertainment for 15 years. Whiz Kids are best known for their award-winning early-childhood education programme, Tsehai Loves Learning, a puppet and animation education series that 'educates children about topics ranging from public health to ethics to literacy, helping to prepare children for school and life at an early age' (Whiz Kids Workshop, 2020). Run by the founders, Etzenhouser and Tigabu, Tsehai Loves Learning is the only educational television programme in Ethiopia (as explained by Tigabu in an interview with the authors on 27 July 2020), run by a team consisting of thirty full-time staff and a hundred members of staff on short-term contracts.

Whiz Kids Workshop uses film as a means through which to educate, entertain and inform young people about issues and topics relating to their lives in Ethiopia. In this case, use of film within an educative setting is more instrumental, and the consumption of film is a vehicle for education in itself. James et al. (2011: 354) state that:

as educators working in the area of anti-colonial and anti-oppressive education - we often use videos and films, not only to provide insights into the lives of young people, but also to help us engage them in critical examination and self-reflection regarding how individual, institutional, and structural factors account for the social and personal circumstances in 
which we find ourselves. Through sound, images, and movement, videos and films can enable new, innovative, and analytical ways of seeing and relating to the world around us and offer different pedagogical possibilities than other educational resources, such as textbooks, provide.

Whiz Kids Workshop uses animation in particular as an entertaining method for showing children what is happening in the world around them. Rather than being based on preconceived or universal ideals of film education, these educational endeavours focus on local topics for local children. This necessary focus on their locality was put into play in particular during the COVID-19 pandemic.

The closure of schools as a result of the lockdown beginning in Ethiopia on 16 March 2020 prompted Whiz Kids to consider children's access to learning resources during this period. As the only educational television programme in Ethiopia, Whiz Kids became involved with broader efforts on a national level to look for opportunities outside the classroom to engage children and facilitate learning. Ethiopia's Ministry of Education developed a response plan to the pandemic, encouraging the continuation of learning during lockdown, stating that, 'the strategies provide recommendations for the continuity of learning at all levels while schools are closed due to COVID-19 including the use of digital technology such as e-learning secondary education and multi-media channels for primary schools' (quoted in Hagos Hailu, 2020). The Ethiopian government also invested in creating spaces for learning on radio, television and online. Internet penetration is very low in Ethiopia, with only 17.8 per cent of people having access to data (Internet World Stats, 2020), and thus radio and television are more widely consumed.

With the responsibility for education falling on parents and caregivers, Whiz Kids Workshop developed projects directed at parents, helping them to cope with the stress of the pandemic. In doing so, they created an information website in Amharic (the most widely spoken language in Ethiopia) and five other languages, linking to relevant information about COVID-19 from the World Health Organization, and other resources, ensuring that parents with internet access were able to access information. In addition to this, they developed educational content to support parents educating their children in reading skills, vocabulary and comprehension through film. They also developed a series of Tsehai Loves Learning episodes tackling COVID-19, wherein the lead character, Tsehai, explained the nature of the virus, how it is transmitted and how one should behave. These episodes were made available online, on television platforms and on radio. As Tigabu explained in the interview, 21 broadcasters showed the COVID-19 information videos prior to every episode of Tsehai Loves Learning, and the government paid for the requisite airtime, totalling two thousand minutes between March and August 2020.

The Ministry of Education encouraged primary school learners to listen to radio, while secondary school students were encouraged to view lessons on television (Tibebu Tiruneh, 2020). Unfortunately, however, 80 per cent of the Ethiopian population live in rural areas with limited access to electricity, making learning via platforms contingent upon access to both the requisite devices and the internet unrealistic (Tibebu Tiruneh, 2020). In addition, families and neighbours who might previously have shared devices were unable to do so, due to the physical distancing measures prohibiting the meeting of households. This unfortunately meant that some children across Ethiopia did not have access to education at all (Hagos Hailu, 2020). During our interview, Tigabu mentioned that the internet had been down for two weeks across Ethiopia, and in response Whiz Kids sent out DVDs, so that those who had been accessing content using the internet were still able to engage. 
In the absence of better infrastructure at a national level allowing for wider access to content through devices, Whiz Kids have been showing their content through a range of media, including radio, television, online and DVD, to ensure that it has as wide a reach as possible. Alongside this, they have been striving for diverse on-screen representation through creating episodes in different languages (their content is primarily produced in Amharic), and including representation of children with disabilities. In the interview, Tigabu explained that they work with 21 broadcasting channels, including television and radio, and currently reach approximately 2.5 million children per episode.

Through their understanding of local audiences, Whiz Kids Workshop worked within their regional context to find important educational solutions during a time of crisis. Due to digital access constraints pertaining to linguistic barriers, and local restrictions on geographic and digital roll-out in rural areas, Whiz Kids' endeavours were unable to find a universal reach across Ethiopia.

\section{My \#QuarantineLife - Argentina and the Netherlands}

My \#QuarantineLife is an initiative between Argentina and the Netherlands undertaken through Free Press Unlimited, and coordinated by Jan-Willem Bult (the Netherlands) and Aldana Duhalde (Argentina). Free Press Unlimited is an organization that seeks to ensure freely available access to reliable information, believing that citizens need to be informed in order to make decisions. To this end, the organization devises projects to ensure that as many voices as possible are able to participate in news dissemination (Free Press Unlimited, 2020). My \#QuarantineLife has formed a key part of this, creating space for children (up to 18 years of age) from across the world to reflect upon their experiences during COVID-19. Through creating platforms on YouTube, Facebook, Twitter and TikTok, the project has become a gateway for children to share their stories and experiences during lockdown. Tutorials explaining how to create films for the project were made available on the Free Press Unlimited website, along with formatting and upload instructions. Films could be made and uploaded in any language, and were subtitled in English, Spanish and Dutch.

The project was keen to mount a contemporary response, utilizing online technologies to ensure that children were able to contribute to on-screen narratives and understandings of the COVID-19 pandemic. For the coordinators of My \#QuarantineLife, film education served as a medium to give young people a voice during the pandemic. The project started through their networks, and then organically expanded through partnerships with other children's organizations across the world, including through CIFEJ - a global network of audiovisual media professionals, including festivals and film organizations, working for children and young people.

The project was not particularly concerned with the quality of the filming, and video quality varied considerably, from professional-standard animation and editing to rudimentary camera phone footage. Each video responded to the call, ultimately developing a platform that could connect children across the world. According to Projector Coordinator Aldana Duhalde, interviewed by the authors on 27 July 2020, for those who engaged and participated, the programme provided a means of connecting with children from different socio-economic backgrounds, cultural contexts, geographical locations, races and genders, and provided a way of exchanging around a common crisis internationally. 
Although they had a remit of sharing lockdown stories, the organization did not act as co-creators, and left the development and execution of the short films entirely in the hands of the young film-makers, allowing them to guide themselves through the process (Chambers, 2019). This singular authorship might be considered a particular product of the COVID-19 era, given how often the creation of a film involves a number of different adult voices, particularly in a classroom setting surrounded by peers and teachers (Chambers, 2019). This project therefore created a space for children to express themselves through film outside curricula (Donald, 2019).

Children shot the films themselves, or received help from their parents, and the films show a wide variety of home life and different levels of privilege. For example, Rodrigo (San Cristóbal de las Casas, Chiapas, Mexico) filmed himself looking after his chickens and documented his processes of storytelling through art; Aida and Hadis (Iran), and Luwan (San Cristóbal de las Casas, Chiapas, Mexico), created beautiful animations; Malindi (Lusaka, Zambia) talked about the importance of African Freedom Day, which took place during lockdown; Wylie (New York, USA) played the drums; and Elizabeth (Santa Clara, Cuba) showed how she uses her imagination with puppets, playing with her father and mother. Others shared magic tricks, musical talent, their fears of going back to school, the loneliness of being away from friends, and stories from children with disabilities, autism and Asperger syndrome, each one connecting children and helping those who could access the platform to connect and learn from children across the world, as Duhalde explained in our interview.

Although emanating from Argentina and the Netherlands, the project is not geographically located, and thus provides a compelling study of intersectionality in a relatively global, 'universal' setting, facilitating the interaction of children from different countries, cultures, socio-economic classes and languages coming together within a digital space to share their experience of lockdown during the pandemic. In doing so, the project created content representative of several different sociocultural experiences from highly disparate locations around the world. The limitations of this project are clear, however. As Duhalde discussed in the interview, those who wished to participate were required to have access to a mobile phone, tablet or another filming device, either within their own household, or one shared with their close family or neighbours. This inevitably created barriers for those who do not have data access, prohibiting and excluding them from viewing the content and engaging with the programme.

The project nevertheless had a limited global reach and engagement, and within three and a half months, the project had received a hundred videos, and had equal participation by boys and girls. In terms of age, 13 per cent of children were up to 6 years old, 57 per cent were between 7 and 12, and 30 per cent were between 13 and 17. The project received videos from a wide range of countries, including Argentina (16 stories), Bolivia (2), Brazil (1), Colombia (1), Cuba (3), Ecuador (7), England (1), Germany (1), Iran (2), Italy (2), Kosovo (3), Mexico (28), Myanmar (1), Nepal (6), the Netherlands (2), Peru (1), Spain (1), Surinam (1), Tunisia (2), Turkey (2), Ukraine (4), the USA (7) and Zambia (5).

As Duhalde stated in the interview, the programme illustrated that:

children are isolated, but they are not alone. Through the project, you can see the filming and creativity inspired them, and you can see the family relationship, the outfits, their expressions, their languages. Children don't have all the solutions, the crisis is extremely complicated, but they have the right to be listened to. This was the core of the project. 
According to Frimberger (2017: 6):

critical education positions the student, with her past life experiences and future hopes, at the centre of the educational encounter. Entrusted to act as a responsible subject, the student enters a dialogic educational space. Here, she does not just receive knowledge from an expert educator but plays an active role in setting the educational agenda as well as educating others by drawing on her past experiences and capabilities. In other words, the student-teacher relationship is democratised.

The project was limited in reach because the intersectional limitations related to the networks of the two organizers, and to wider societal contexts, acted as gatekeepers to participation in the programme, as lack of digital access prohibited the equitable roll-out of the initiative, but it was still able to centre children's experience of COVID-19 across the world, providing a space for them to share their own experiences. Despite the benefit of intercultural exchange, one must consider who was left out of this initiative, and the resulting impact upon the project's aspirations to create a global film education forum. Although My \#QuarantineLife had universal possibilities in scope, contextual circumstances and structural limitations prevented these from being fully accessible.

\section{Takalani Sesame - South Africa}

In South Africa, both Takalani Sesame and the Children and Broadcasting Foundation for Africa (CBFA) developed public service announcements to inform young people during the COVID-19 pandemic. Takalani Sesame is the South African version of the US children's television programme Sesame Street. The programme expanded to South Africa in 2000, and it aims to address 'a range of early childhood development needs - from literacy, mathematics and life skills, to instilling in children a greater sense of self and nurturing their readiness for lifelong learning' (Sesame Workshop, 2020). The show is broadcast on weekdays on the South African Broadcasting Corporation (SABC), a free-to-air public broadcaster. Episodes are made in 5 of South Africa's 11 official languages, and they follow Elmo, Zuzu and a number of other characters with local names. The show is aimed at children between the ages of 0 and 6 years. During the COVID-19 pandemic, the department of education and the SABC launched educational television and radio initiatives to assist with learning during school closures, including the Takalani Sesame programmes (World Bank, 2020). Erika Jooste works as the Gender Advisor and Melissa Kribashnee Chetty works in Partnerships and Business Development at Sesame Workshop International, South Africa. During an interview with the authors on 29 July 2020, they explained that while Takalani Sesame create their own local series, due to funding limitations, they still rely on Sesame Workshop in the US for ancillary content, some of which is developed so that it is context specific. Given this reliance on American content in South Africa, one could ask how does the intercultural relationship between the two organizations play out, and what impact does this have on the intersectional representations by Takalani Sesame in South Africa (Frimberger, 2017).

During the COVID-19 pandemic, Takalani Sesame used public service announcements created by Sesame Workshop US, including 'Washy wash with Elmo', through which children learnt the importance of washing their hands; 'Learning how to sneeze and cough safely with Grover', which teaches children to sneeze into their elbow; and 'Time to wash your hands', which teaches children the instances when they 
should wash their hands. Takalani Sesame subsequently received funding from the Oak Foundation, an international organization working to address issues of global and social concern, to dub these public service announcements into 4 (out of 11) South African official languages. 'Time to wash your hands' incorporates a 'tippy tap', a hands-free device for washing hands in areas with no running water. These devices are prevalent in lower socio-economic areas across South Africa, thus adding local context to the public service announcement broadcasts. These short episodes were broadcast on Takalani Sesame's social media platforms, YouTube and Facebook, reaching over six thousand views per public service announcement. Further to this, Sesame Workshop US received a grant from the Lego Foundation to create an 'Elmo news special', a thirty-minute episode where Elmo speaks with his fellow 'reporters' across the world to explain to children how to cope during the pandemic, and how to connect with friends during this period. This was produced by the Sesame Workshop US, dubbed in local languages and broadcast on SABC, reaching an estimated 4.2 million children per broadcast.

Currently, to engage with Takalani Sesame's content, viewers are required to have an online device or television. As Takalani Sesame draws its content from the US Sesame Street, its content might thus be said to embody a universal approach facilitated through local application. Although the relationship between Takalani Sesame and the US Sesame Street seems to have an element of intercultural understanding by which intersectional understandings of content are able to be taken into account to some extent, through the use of local languages and imagery, the power dynamics and structural inequities between the two countries need to be taken into consideration, in addition to local understandings and the level of autonomy concerning their locality.

\section{The Children and Broadcasting Foundation for Africa - South Africa}

The Children and Broadcasting Foundation for Africa (CBFA) was founded in 1995 following the first World Summit on Media for Children, held in Melbourne, Australia. The CBFA works as a collective to ensure that children's film and media content is developed, discussed and monitored across Africa. The foundation strives to ensure that children in Africa 'hear, see and express themselves, their culture, their language and their life experiences, through the electronic media which reaffirm their sense of self, community and place' (Article 4 of the 1997 Africa Charter on Children's Broadcasting). It works to monitor children's content across Africa, and it created the Africa Charter on Children's Broadcasting through a series of summits, including the Southern African Summit in 1996 (Johannesburg, South Africa), the All Africa Summit in 1997 (Accra, Ghana), and the fifth World Summit on Media for Children in 2007 (Johannesburg, South Africa), which it hosted. The charter went on to provide the guidelines for children's programming for all African and Commonwealth broadcasters. Further to this, the CBFA has also created content and worked with UNICEF and a range of other partners across the continent to create television series, films and animations for children.

The CBFA has recently partnered with the African Animation Studio (AAS) and South African production company Moments Entertainment to develop the animation series Wazi's Wonderful World, following an 8-year-old girl, Wazi, who goes out to learn about and explore the African continent. The series aims to teach children about African heritage and culture as Wazi travels with her younger brother Musa to locations across the continent. Similar to Takalani Sesame, as COVID-19 hit South Africa, the series adapted to create a number of short animations informing and advising children 
about the implications of COVID-19. The series producer Firdoze Bulbulia (one of the authors of this paper) stated in 2020 that:

... as we realized that lockdown was looming due to the pandemic, we thought it would be important to communicate with children and their caregivers about COVID-19. So instead of going out to explore the wonderful world, Wazi is told to stay at home. Our concerns were that children will be lost in broader communication and information dissemination, and we needed to immediately offer solutions for children, we needed it to be short, factual and fun animations that children could identify with.

Since March 2020, the producers of Wazi's Wonderful World have created 25 short animations, each between thirty and ninety seconds long, including two for the World Bank. In the first episode, Wazi rushes to the window with her brother Musa to look at the world outside, before seeing a noticeboard displaying a poster telling her to 'stay home'. Her subsequent adventures change to learning about living during COVID-19. Other episodes educate children about the importance of washing hands, of wearing a mask, of the changes they might find when going back to school, and of dealing with COVID-19 with a disability, depicted through Wazi's best friend Jozi, who uses a wheelchair. Wazi's Wonderful World has also sought to explore how children are coping with COVID-19 in different situations across the country, for example, incorporating live action video from the Eastern and Western Cape of children saving water while still washing their hands. Content was launched on the Wazi's Wonderful World social media platforms (including Facebook, Instagram, Twitter and WhatsApp). The South African National Department of Health embedded the content on their website, and as the animations began to gain traction, they were acquired by a number of different broadcasters and organizations, including Multichoice - Channel 405 Newsroom Afrika (Africa), MiTV (Nigeria), the Asia Broadcasting Union (Asia), ETV South Africa, and the Specialized Association of Children and Media in Iran, who incorporated Persian (Farsi) characters in order to share the content on their media and broadcasting platforms. ETV broadcast the COVID-specific Wazi animations 958 times; according to subsequent evaluation in an internal ETV report, 72 per cent of children watching these were between 1 and 14 years old, and 28 per cent were 15 and over.

The reception and engagements with both Takalani Sesame and the CBFA were impacted by the unique historical trajectory of South Africa, which - due to the history of apartheid - is shaped by a significant intersection of racial and class inequality. As a result, South Africa currently has some of the highest levels of inequality of any country in the world (Stats SA, 2020). This inevitably impacts the way in which educational content is disseminated across the country, because it is often those from Black communities and low socio-economic backgrounds who have less access to data. Due to data restrictions, only 55 per cent of people in South Africa have access to data (mainly in middle and upper socio-economic households (Internet Live Stats, 2020)), and for this reason, television and radio broadcasts currently remain the most effective way of reaching wider audiences on a national level. As Erika Jooste and Melissa Kribashnee Chetty of Sesame Workshop International, South Africa, explained in our interview, access to data in South Africa remains prohibitively expensive, thus excluding much of the population from taking part in online learning activities. Limited dissemination on digital platforms can therefore be seen to be entrenched in societal contexts, even when operating on an international level, as is the case with Takalani Sesame. 


\section{Conclusion}

This paper has sought to bring together a diverse range of case studies from across the world in an attempt to demonstrate how consumption of media is impacted by microand macro-levels of intersectionality and the multimodality of film education. Although the common experience of the COVID-19 pandemic necessitated digital transition to education through film and media in most countries, access to digital media has not been universal, and it is affected by divergent intersectional factors, each specific to the context in which it is operating. The digital transition during COVID-19 took film education beyond the classroom, and necessitated different forms of learning, from film clips and information videos, to film-making and film viewing. Whiz Kids International, Takalani Sesame and CBFA all created a series of educational content and public service announcements designed to inform children about the crisis. These were disseminated online, and on television and radio, using film in an instrumentalized manner as an educational tool. These initiatives provided local content for local audiences, yet the dissemination in each country was impacted by low internet access and intersectional differences. My \#QuarantineLife gave children across the world a platform to share and express their experiences during COVID-19, using the digital platforms to facilitate independent film-making activities through which children were free to express themselves. Although the project was able to bring together an intersection of global stories during COVID-19, it was only accessible to those in possession of a mobile device to create, upload and view the content. In India, SIFFCY was able to transition to a digital festival; because of this, it was not bound by physical location, and was thus able to reach children across the country, in both rural and urban areas. Digital platforms also enabled SIFFCY to bring together a number of international speakers to share their work, a unique opportunity that in certain respects was directly facilitated by the COVID-19 lockdown. Despite these positive shifts, we argue that access to digital content remains impacted by class, region, language and access to technology. Through analysis, the case studies highlight the need for a contextual understanding of film education, as the role of the passeur and intersectional influences uniquely impacted the response of each country to COVID-19. In conclusion, we feel that there is an imperative for film education discourses - both during and beyond the COVID-19 pandemic - to move beyond Western-centric perspectives, to incorporate intersectional perspectives which can usefully illuminate a greater diversity of knowledge systems, pedagogical approaches and global educational practices.

\section{Notes on the contributors}

Justine Atkinson is the founder and director of Aya Films, an international distribution company with a focus on African cinema and curatorial training. She worked as the Festival Producer of the Africa in Motion film festival between 2013 and 2019. She is currently pursuing a $\mathrm{PhD}$ on the theory of collaborative curation at the University of Glasgow, UK.

Firdoze Bulbulia is a South African activist, theatre director, producer, writer and educator. She is Co-Director of Moments Entertainment, a media company with a focus on media education and film production. Throughout her career, Firdoze has been involved as an activist in women's and children's movements, using theatre and art as media of expression and for conflict resolution. She is currently undertaking a PhD entitled '\#MemoryisaWeapon: The personal is political' at the University of Johannesburg, South Africa. 


\section{References}

Akande, L. (2020) 'Film education pedagogy in Nigeria: A nation-specific approach to a nonWestern university curriculum'. Film Education Journal, 3 (1), 1-12. https://doi.org/10.14324/ FEJ.03.1.01.

Bachmann, A. and Zahn, M. (2018) 'Film education as a multiplicity of practices: A media-ecological perspective'. Film Education Journal, 1 (1), 78-89. https://doi.org/10.18546/FEJ.01.1.07.

BBC News (2020) 'India coronavirus: Online classes expose extent of digital divide'. 22 July. Accessed 5 August 2020. www.bbc.co.uk/news/world-asia-india-53471749.

Bergala, A. (2016) The Cinema Hypothesis: Teaching cinema in the classroom and beyond. Trans. M. Whittle. Vienna: FilmmuseumSynemaPublikationen.

Chambers, J. (2018) 'Towards an open cinema: Revisiting Alain Bergala's The Cinema Hypothesis within a global field of film education'. Film Education Journal, 1 (1), 35-50. https://doi.org/10.18546/ FEJ.01.1.04.

Chambers, J. (2019) 'Exploring co-creation in practical film education from primary school to postgraduate study: Theoretical and auto-ethnographic perspectives upon teaching film practice'. Film Education Journal, 2 (1), 27-47. https://doi.org/10.18546/FEJ.02.1.03.

Collins, P.H. (1990) Black Feminist Thought: Knowledge, consciousness, and the politics of empowerment. New York: Routledge.

Crenshaw, K. (1991) 'Mapping the margins: Intersectionality, identity politics, and violence against women of color'. Stanford Law Review, 43 (6), 1241-99. https://doi.org/10.2307/1229039.

DeHart, J.D. (2020) 'Living in a "digital world": An ethnographic study of film and adolescent literacy education in rural secondary schools in America'. Film Education Journal, 3 (1), 46-57. https://doi.org/10.14324/FEJ.03.1.04.

Donald, S.H. (2019) 'Follow the yellow brick road: The passeur, the gatekeeper and the young migrant film-maker'. Film Education Journal, 2 (1), 48-61. https://doi.org/10.18546/FEJ.02.1.04.

Free Press Unlimited (2020) 'Sharing the stories of the youth in My \#QuarantineLife'. 27 March. Accessed 1 August 2020. www.freepressunlimited.org.

Frimberger, K. (2017) 'The ethics of performative approaches in intercultural education'. In J. Crutchfield and M. Schewe (eds), Going Performative in Intercultural Education: International contexts, theoretical perspectives and models of practice. Bristol: Multilingual Matters, 21-41.

Gibbs, A. (2018) 'Film education otherwise: A response to Bergala's dialectics of cinema and schooling'. Film Education Journal, 1 (1), 90-100. https://doi.org/10.18546/FEJ.01.1.08.

Gross, C., Gottburgsen, A. and Phoenix, A. (2016) 'Education systems and intersectionality'. In A. Hadjar and C. Gross (eds), Education Systems and Inequalities: International comparisons. Bristol: Policy Press.

Hagos Hailu, B. (2020) 'Education response to COVID-19: How can basic education be implemented in Ethiopia?'. UKFIET: The Education and Development Forum. 11 May. Accessed 5 August 2020. www.ukfiet.org/2020/education-response-to-covid-19-how-can-basic-educationbe-implemented-in-ethiopia/.

Internet Live Stats (2020) 'South Africa internet users'. Accessed 10 August 2020. www.internetlivestats.com/internet-users/south-africa/.

Internet World Stats (2020) 'Internet user statistics for Africa: 2020 - Q1 - March'. Accessed 10 August 2020. www.internetworldstats.com/stats1.htm.

James, C.E., Marin, L. and Kassam, S. (2011) 'Looking through the cinematic mirror: Film as an educational tool'. Review of Education, Pedagogy, and Cultural Studies, 33 (4), 354-64. https://doi.org/10.1080/10714413.2011.597647.

Misra, S. and Mishra, N.L. (2020) 'Digital divide in India's education'. The Statesman. 13 June. Accessed 10 August 2020. www.thestatesman.com/opinion/digital-divide-indias-education-1502899472.html.

Nash, J. (2008) 'Re-thinking intersectionality'. Feminist Review, 89 (1), 1-15. https://doi.org/10.1057/ fr.2008.4.

Nelson Mandela Children's Fund (2021) 'Nelson Mandela quotes about children'. Accessed 12 May 2021. https://www.nelsonmandelachildrensfund.com/news/nelson-mandela-quotes-about-children.

Núñez, A.-M. (2014) 'Employing multilevel intersectionality in educational research: Latino identities, contexts, and college access'. Educational Researcher, 43 (2), 85-92. https://doi.org/10.3102/0013189X14522320.

Oxfam International (2021) 'India: Extreme inequality in numbers'. Accessed 9 August 2020. www.oxfam.org/en/india-extreme-inequality-numbers.

Sesame Workshop (2020) 'Takalani Sesame: Educating and entertaining South African children for nearly two decades'. Accessed 3 March 2021. https://stage.sesameworkshop.org/what-we-do/ shows/takalani-sesame. 
Smile Foundation (2020) 'About Smile Foundation'. Accessed 1 August 2020 www.smilefoundationindia.org.

Stats SA (2020) 'How unequal is South Africa?'. 4 February. Accessed 13 August 2020. www.statssa. gov.za/?s=GINI\%20COEFFICIENT\&pg=0.

Tibebu Tiruneh, D. (2020) 'COVID-19 school closures may further widen the inequality gaps between the advantaged and the disadvantaged in Ethiopia'. Cambridge University Press, Cambridge Partnership for Education blog. Accessed 9 August 2020. www.cambridge.org/gb/ educationreform/insights/covid-19-school-closures-may-further-widen-inequality-gaps-betweenadvantaged-and-disadvantaged-ethiopia/.

Whiz Kids Workshop (2020) 'Tsehai loves learning'. Accessed 9 August 2020. www.whizkidsworkshop. com/projects/tsehai/.

World Bank (2020) 'How countries are using edtech (including online learning, radio, television, texting) to support access to remote learning during the COVID-19 pandemic'. Accessed 9 August 2020. www.worldbank.org/en/topic/edutech/brief/how-countries-are-using-edtech-tosupport-remote-learning-during-the-covid-19-pandemic. 